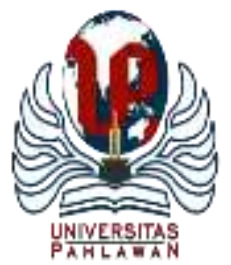

Edukatif : Jurnal Ilmu Pendidikan Volume 4 Nomor 1 Tahun 2022 Halm 1498 - 1509

EDUKATIF: JURNAL ILMU PENDIDIKAN

Research \& Learning in Education

https://edukatif.org/index.php/edukatif/index

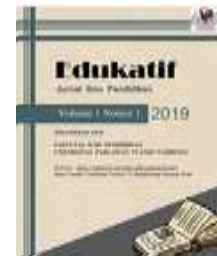

\title{
Pengaruh Google Classroom, Intensitas Pemberian Tugas, dan Fasilitas Belajar Terhadap Hasil Belajar Akuntansi Manajemen pada Mahasiswa Pendidikan Akuntansi
}

\author{
Venyta Dwi Agmerda ${ }^{1 凶}$, Suci Rohayati \\ Universitas Negeri Surabaya, Indonesia ${ }^{1,2}$ \\ E-mail : venyta.18003@mhs.unesa.ac.id ${ }^{1}$ sucirohayati@ unesa.ac.id $^{2}$
}

\begin{abstract}
Abstrak
Mengimplementasikan pembelajaran online di Indonesia dapat dikatakan tidak begitu mudah, karena berlangsungnya proses pembelajaran terdapat kendala serta dampak yang dapat ditimbulkan Hal ini dapat mempengaruhi pencapaian mahasiswa dalam mengikuti pembelajaran. Penelitian ini dilakasankaan dengan tujuan sebagai bahan analisa perihal pengaruh google classroom, intensitas pemberian tugas, dan fasilitas belajar terhadap hasil belajar akuntansi manajemen. Dalam pengambilan sampel memanfaatkan teknik sampel jenuh melalui suatu instrument yang bernama kuisioner dengan jumlah keseluruhan sampel yakni 61 responden dari mahasiswa Pendidikan Akuntansi Angkatan 2018. Sebagai upaya guna memberikan hasil yang tepat, data kemudian dianalisa melalui teknik regresi linier berganda. Hasil yang didapatkan yakni secara simultan ada pengaruh secara positif serta signifikan antara google classroom, intensitas pemberian tugas dan fasilitas belajar terhadap hasil belajar akuntansi manajemen pada mahasiswa pendidikan akuntansi.
\end{abstract}

Kata Kunci: Google Classroom, Intensitas Pemberian Tugas, Fasilitas Belajar dan Hasil Belajar Akuntansi Manajemen

\section{Abstract}

Implementing online learning in Indonesia can be said to be easy, because of the ongoing learning process and the impact that can be caused. This cannot affect students in participating in learning. This research was conducted with the aim of being used as material for analysis, of the effect of Google classroom, assignment, and learning facilities on management accounting learning outcomes. In sampling, using the saturated sample technique through an instrument called a questionnaire with a total sample of 61 respondents from Accounting Students Class 2018. In an effort to provide accurate results, the data is then analyzed through multiple linear regression techniques. The results obtained are that there is simultaneously a positive and significant influence between Google Classroom, presenting assignments, and learning facilities on the learning outcomes of management accounting in accounting education students.

Keywords: Google Classroom, Intensity of Giving Assignment, Learning Facilities, Management Accounting Learning Outcomes

Copyright (c) 2022 Venyta Dwi Agmerda, Suci Rohayati

$\triangle$ Corresponding author:

Email : venyta.18003@mhs.unesa.ac.id

DOI : https://doi.org/10.31004/edukatif.v4i1.2243

ISSN 2656-8063 (Media Cetak)

ISSN 2656-8071 (Media Online)

Edukatif : Jurnal Ilmu Pendidikan Vol 4 No 1 Tahun 2022

p-ISSN 2656-8063 e-ISSN 2656-8071 
1499 Pengaruh Google Classroom, Intensitas Pemberian Tugas, dan Fasilitas Belajar Terhadap Hasil Belajar Akuntansi Manajemen pada Mahasiswa Pendidikan Akuntansi - Venyta Dwi Agmerda, Suci Rohayati

DOI: https://doi.org/10.31004/edukatif.v4i1.2243

\section{PENDAHULUAN}

Hadirnya wabah COVID-19 mempengaruhi tingkatan sektor dan salah satunya ialah sektor pendidikan. Sehingga untuk meminimalisir penyebaran wabah ini, pemerintah mengeluarkan suatu kebijakan yakni meliburkan keseluruhan lembaga pendidikan (Anugrahana, 2020). Hal tersebut membuat kegiatan pembelajaran diwajibkan dijalankan secara online, dan tidak bisa dijalankan dengan tatap muka (Basar, 2021)

Pembelajaran online dilaksanakan dengan memanfaatkan jejaring internet dan web 2.0, ini bermaksud bahwasanya penerapan pembelajaran daring didukung dengan adanya teknologi sebagai alat dan jejaring internet pada suatu sistem (Alessandro, 2018) Dengan model pembelajaran online ini, mahasiswa diharapkan tetap mengikuti proses pembelajaran karena pendidikan sangat penting bagi keberlangsungan kehidupan manusia dan dianggap efektif, terutama di perguruan tinggi. Lembaga pendidikan dalam konteks ini suatu universitas ataupun perguran tinggi berperan dalam mengimplementasikan pendidikan guna membentuk sumber daya manusia dengan memiliki mutu. (Ervina \& Rohayati, 2013)

Program Studi Pendidikan Akuntansi berkontribusi dalam tercetaknya lulusan menjadi sebagai tenaga pendidik ataupun akuntan. Akuntansi Manajemen ialah salah satu Mata Kuliah Keilmuan dan Ketrampilan (MKK) Kompetensi yang wajib dipelajari oleh mahasiswa Program Studi Pendidikan Akuntansi Universitas Negeri Surabaya. Berlandas sudut pandang mahasiswa mengenai mata kuliah akuntansi manajemen cukup sulit karena mata kuliah ini merupakan sekumpulan penaksiran dan proses akuntansi sebagai upaya dalam menaksir dan memberikan penilaian pada kinerja orang yang bersangkutan di suatu organisasi melalui indikator kinerja keuangan dan non-keuangan.

Mengimplementasikan pembelajaran online di Indonesia dapat dikatakan tidak begitu mudah, terdapat kendala-kendala yang timbul. Salah satunya adalah terkendala ketidakstabilan sinyal internet dan tarif kuota data yang tidak murah (CIPS Indonesia, 2020). Hal ini dapat mempengaruhi pencapaian mahasiswa dalam mengikuti pembelajaran yang dikenal sebagai hasil belajar. Hasil belajar menunjukkan keterampilan, kemampuan, dan pengetahuan mahasiswa diperoleh mahasiswa dengan satuan nilai yang terukur dan diperoleh setelah mahasiswa menyelesaikan proses pembelajaran. Dengan penerapan pembelajaran online, perolehan hasil belajar yang optimal sangat bergantung kepada kemampuan mahasiswa dalam beradaptasi selama pembelajaran (Seto et al., 2020) Akan tetapi, pada realisasinya kebanyakan mahasiswa memperoleh nilai yang begitu rendah dan perlu mengulang mata kuliah ini. Sehingga dapat disebutkan bahwasanya pada hasil belajar akuntansi manajemen kurang maksimal. Hal ini dibuktikan dengan hasil study pendahuluan yang dilakukan peneliti menggunakan kuisioner observasi data awal dengan hasil 84,8\% mahasiswa Pendidikan Akuntansi Angkatan 2018 merasa kesulitan dalam menempuh Matakuliah Akuntansi Manajemen. Hal ini karena kurangnya pemberian intensitas latihan soal sebesar $66,7 \%$ dan pemanfaatan e-learning yang kurang maksimal sebesar 30,3\%. Dari hasil tersebut dapat dipastikan adanya beberapa faktor yang bisa mempengaruhi hasil belajar akuntansi manajemen.

Faktor pertama diduga mampu mempengaruhi yakni Google Classroom. Di dalam google classroom menyediakan sarana berupa kelas dimana pengguna bisa mengaksesnya melalui Google Apps for Education, sekumpulan alat yang digunakan untuk produktif tanpa dibebani biaya meliputi gmail, dokumen, dan drive (Hammi, 2017) Hal ini bertujuan supaya institusi pendidikan mampu mempermudah pembuatan, pembagian, dan pengimplementasian tugas yang paperless (Suhada et al., 2020) Teori ini berjalan sebanding dengan penelitian yang telah dilakukan oleh (Afrianti, 2018) dengan hasil penelitian yang menunjukkan bahwa pembelajaran online melalui Google Clasroom memiliki pengaruh yang positif terhadap kemajuan belajar para siswa pada pemeblajaran Akuntansi, dengan demikian pembelajaran melalui Google Classroom dapat meningkatkan hasil belajar siswa secara signifikan. Berjalan sebanding dengan hasil penelitian Berbeda 
1500 Pengaruh Google Classroom, Intensitas Pemberian Tugas, dan Fasilitas Belajar Terhadap Hasil Belajar Akuntansi Manajemen pada Mahasiswa Pendidikan Akuntansi - Venyta Dwi Agmerda, Suci Rohayati

DOI: https://doi.org/10.31004/edukatif.v4i1.2243

dengan hasil penelitian dari (Kristiana Nia, 2020) yang mengemukakan adanya pengaruh negatif penggunaan google classroom dalanm pembelajaran online pada hasil belajar.

Selain pengaruh Google Classroom, terdapat pula faktor kedua yang dispekulasi mampu memberikan pengaruh yakni intensitas pemberian tugas. Pemberian tugas pada masa pembelajaran online dapat meningkatkan rasa tanggung jawab pada mahasiswa dalam ketepatan waktu pengumpulan dikarenakan apabila terlewat dapat mempengaruhi hasil belajar (Susilo \& Pancarani, 2020) Hal ini dapat diartikan tugas yang diberikan Dosen kepada para mahasiswanya sebagai bentuk umpan balik untuk penilaian (assessment) atas proses pembelajaran pada saat berlangsung. Menurut (Parni \& Listiadi, 2020) Pemberian tugas yang dilakukan secara intens akan berdampak positif terhadap hasil belajar namun dengan signifikan yang lemah sebesar 9\%. Sesuai dengan penelitian (Suhada et al., 2020) mengemukakan bahwa intensitas pemberian tugas berpengaruh secara positif dengan signifikansi lemah pada hasil belajar sebesar 0,096. Berbeda dengan penelitian (Astuti et al., 2018) mengemukakan bahwasanya teknik memberikan suatu tugas pada pembelajaran daring tidak mempengaruhi hasil belajar secara signifikan.

Faktor ketiga yang diduga dapat mendukung hasil belajar Akuntansi Manajemen secara online atau daring antara lain Fasilitas Belajar. Menurut (Sadikin \& Hamidah, 2020) fasilitas belajar bisa ditentukan dengan sumber belajar, alat belajar dan pendukung belajar. Masalah dalam pembelajaran online antara lain pengawasan yang lemah, biaya kuota yang mahal dan jaringan yang buruk di daerah pelosok (Sadikin \& Hamidah, 2020) Terdapat beberapa komponen yang dapat mengukur keberhasilan belajar melalui fasilitas, antara lain, hubungan media belajar dengan alat bantu pembelajaran, perlengkapan serta lingkungan belajar (Hammi, 2017) Proses pembelajaran akan berlangsung dengan baik dan tercapai tujuan pembelajaran apabila fasilitas belajar yang terpenuhi. Penelitian (Fijar et al., 2018) menyatakan bahwa hasil belajar dipengaruhi oleh fasilitias belajar di rumah sebesar $30,5 \%$ dengan signifikansi tinggi. Sesuai dengan penelitian membuktikan bahwa fasilitas belajar berkontribusi pada hasil belajar sebesar 28,6\% dan signifikansinya $<0,05$. Berbeda dengan hasil penelitian (Kristiana Nia, 2020) bahwa adanya suatu pengaruh negatif dari fasilitas belajar pada hasil belajar.

Urgensi penelitian ini adalah untuk menganalisis pengaruh Google Classroom, Intensitas Pemberian Tugas dan Fasilitas Belajar terhadap hasil belajar Akuntansi Manajemen pada Mahasiswa Pendidikan Akuntansi. Dengan berhipotesiskan secara simultan dan parsial. Hipotesis yang terbentuk pada penelitian ini yaitu Google Classroom, Intensitas Pemberian Tugas dan Fasilitas Belajar berpengaruh simultan terhadap hasil belajar Akuntansi Manajemen, ada pengaruh Google Classroom terhadap hasil belajar Akuntansi Manajemen, ada pengaruh Intensitas Pemberian Tugas terhadap hasil belajar Akuntansi Manajemen, serta Fasilitas Belajar mampu mempengaruhi hasil belajar Akuntansi Manajemen.

\section{METODE PENELITIAN}

Jenis penelitian menurut (Sugiono, 2014) terdiri atas penelitian kuantitatif dan kualitatif. Dalam penelitian ini masuk dalam kategori penelitian kuantitatif yang mana sumber data dari hasil pengumpulan sampel penelitian dan selanjutnya data tersebut dikelola dengan dilakukannya uji dan analisis melalui metode statistik serta langkah terakhir diinterpretasikan.

Populasi dan sampel ditujukkan pada mahasiswa Pendidikan Akuntansi Universitas Negeri Surabaya angkatan 2018 dan rinciannya yakni:

Tabel 1

Banyaknya Mahasiswa Pendidikan Akuntansi FEB UNESA angkatan 2018

\begin{tabular}{clcc}
\hline No & Nama Kelas & Populasi & Sampel \\
\hline 1 & PAK 18A & 29 & 29 \\
2 & PAK 18B & 32 & 32 \\
& Jumlah & 61 & 61 \\
\hline
\end{tabular}

Edukatif : Jurnal Ilmu Pendidikan Vol 4 No 1 Tahun 2022 p-ISSN 2656-8063 e-ISSN 2656-8071 
1501 Pengaruh Google Classroom, Intensitas Pemberian Tugas, dan Fasilitas Belajar Terhadap Hasil Belajar Akuntansi Manajemen pada Mahasiswa Pendidikan Akuntansi - Venyta Dwi Agmerda, Suci Rohayati

DOI: https://doi.org/10.31004/edukatif.v4i1.2243

Penentuan sampel dengan teknik sampel jenuh yang berarti keseluruhan anggota populasi merupakan sampel. Menurut (Arikunto, 2002) apabila total dari populasi $>100$, maka akan diambil sampel secara lengkap, namun bila total populasi melebihi 100 orang, maka yang digunakan $10 \%$ sampai $15 \%$ atau $20 \%$ sampai $25 \%$ dari total populasi. Dengan demikian berlandas pada total populasi maka sampel yang digunakan berjumlah 61 mahasiswa S1 Pendidikan Akuntansi Angkatan 2018 UNESA.

Menurut (Suhada et al., 2020) mengemukakan bahwa google classroom mempunyai empat indikator guna menaksir variabel google classroom yaitu respon yang diberikan mahasiswa atas mudahnya pengaksesan, memahami materi pembelajaran melalui google classroom, google classroom efektif pada pembelajaran daring, penggunaan google classroom. Sehingga indikator yang dipakai sebagai pengukur variabel google classroom ialah mengenai bagaimana cara mahasiswa dalam memanfaat media e-learning tersebut secara maksimal. Menurut (Meydiningrum \& Darminto, 2020) variabel intensitas pemberian tugas dapat dilakukan pengukuran menggunakan indikator seperti frekuensi dosen memberikan tugas ke mahasiswa, tugas sesuai materi yang dikemukakan, serta pengerjaan tugas oleh mahasiswa. Sedangkan menurut (Indriyani, 2019) indikator pengukur variabel fasilitas belajar yaitu ruang atau tempat, perabotan, dan alat bantu belajar.

Teknik dalam mengumpulkan data melalui kuisioner yang mana alternative jawabannya menggunakan skala likert. Kemudian data tersebut dilanjutkan ke tahap pengujian validitas dan reliabilitas. Metode statistik dalam pengolahan data selanjutnya yakni analisis regresi linier bergandaserta dilaksanakannya pengujian hipotesis namun sebelum hal tersebut terjadi langkah yang perlu diambil ialah melakukan pengujian asumsi klasik. Pengujian dan penganalisisan melalui SPSS 24.

\section{HASIL DAN PEMBAHASAN PENELITIAN}

Hasil olahan data penelitian ini meunjukkan bahwa hasil variabel penelitian Google Classroom, Intensitas pemberian tugas, Fasilitas belajar memiliki pengaruh terhadap hasil belajar siswa Pendidikan Akuntansi 2018. Dibawah ini merupakan rincian hasil dari analisis statistik deskriptf yang datanya berasal dari pengujian instrument :

\section{Statistik Deskriptif}

Tabel 2

Statistik Deskriptif

\begin{tabular}{lccccc}
\hline & $\mathrm{N}$ & Minimum & Maximum & Mean & Std. Deviation \\
\hline Google_Classroom & 61 & 48 & 80 & 69.26 & 8.675 \\
\hline Intensitas Pemberian Tugas & 61 & 11 & 40 & 27.49 & 9.698 \\
\hline Fasilitas Belajar & 61 & 14 & 32 & 23.11 & 4.282 \\
\hline Hasil Belajar & 61 & 75 & 86 & 79.80 & 2.264 \\
\hline Valid N (listwise) & 61 & & & &
\end{tabular}

Mengacu pada hasil uji statistik deskriptif bahwasanya variabel hasil belajar akuntansi manajemen dengan 38 pertanyaan dikatakan data yang diperoleh valid dan sah untuk dilaksanakannya pengujian lebih mendalama serta valid missing berjumlah 0 , rerata nilai yang didapatkan 79,80 nilai minimumnya 75 dan nilai maksimumnya 86.Oleh karena tersebut maka variabel hasil belajar akuntansi manajemen masuk dalam kategori tinggi. Pada variabel pengaruh google classroom dengan 20 pertanyaan yang telah dianalisa menunujukkan rerata nila 69,26 nilai minimumnya 48 dan nilai maksimumnya senilai 80 . Dengan demikian variabel google classroom masuk dalam kategori tinggi. Kemudian variabel intensitas pemberian tugas yang dengan 10 pertanyaan yang telah dilakukannya analisa maka diperoleh rarat nilai 27,49, nilai minimumnya 11 dan nilai maksimumnya 40. Jadi variabel intensitas pemberian tugas termasuk dalam kategori tinggi. Lalu variabel fasilitas belajar dengan 8 pertanyaan setelah dilakukan analisis, hasil yang diperoleh yakni rerata 
1502 Pengaruh Google Classroom, Intensitas Pemberian Tugas, dan Fasilitas Belajar Terhadap Hasil Belajar Akuntansi Manajemen pada Mahasiswa Pendidikan Akuntansi - Venyta Dwi Agmerda, Suci Rohayati

DOI: https://doi.org/10.31004/edukatif.v4i1.2243

nilainya 23,11 dengan nilai minimumnya 14 dan nilai maksimumnya 32, maka variabel ini masuk ke kategori tinggi.

Selanjutnya dapat dilakukan tahap uji prasayarat untuk menguji data penelitian pada tahap hasil uji analisa linier. Ini merupakan hasil uji normalitas, sebagai acuan bahwa data populasi yang digunakan berdistribusi normal. Hasil uji Normlalitas dijelaskan pada tabel dibawah ini :

\section{Uji Normalitas}

Tabel 3

Metode Kolmogorov Smirnov

\begin{tabular}{|c|c|c|}
\hline \multicolumn{3}{|c|}{ One-Sample Kolmogorov-Smirnov Test } \\
\hline & & Unstandardized Residual \\
\hline $\mathrm{N}$ & & 61 \\
\hline \multirow[t]{2}{*}{ Normal Parameters ${ }^{\mathrm{a}, \mathrm{b}}$} & Mean & .0000000 \\
\hline & Std. Deviation & 2.01286137 \\
\hline \multirow[t]{3}{*}{ Most Extreme Differences } & Absolute & .090 \\
\hline & Positive & .090 \\
\hline & Negative & -.058 \\
\hline \multicolumn{2}{|l|}{ Test Statistic } & .090 \\
\hline \multicolumn{2}{|l|}{ Asymp. Sig. (2-tailed) } & $.200^{\mathrm{c}, \mathrm{d}}$ \\
\hline \multicolumn{3}{|l|}{ a. Test distribution is Normal. } \\
\hline \multicolumn{3}{|l|}{ b. Calculated from data. } \\
\hline \multicolumn{3}{|c|}{ c. Lilliefors Significance Correction. } \\
\hline
\end{tabular}

Hasil analisa uji normalitas sesuai pada tabel 3. Menunjukkan hasil sig. (2-tailed) uji homogenistas berada pada angka 0,200. Sesuai dengan persyaratan uji homogenistas yakni sig (2-tailed) >0,05 maka dinyakan data berdistribusi normal. Dengan demikian melalui hasil uji homogenitas dapat menyimpulkan bahwa keseluruhan populasi bersifat normal, dan dapat dijadikan sebagai alat pengukuran variabel penelitian.

\section{Uji Multikolinearitas}

Tabel 4

Uji Multikolinearitas

\begin{tabular}{|c|c|c|c|c|c|c|c|c|}
\hline \multicolumn{9}{|c|}{ Coefficients $^{\mathbf{a}}$} \\
\hline \multirow[b]{2}{*}{ Mode } & & \multicolumn{2}{|c|}{$\begin{array}{l}\text { Unstandardized } \\
\text { Coefficients }\end{array}$} & \multirow{2}{*}{$\begin{array}{l}\text { Standardid } \\
\text { Coefficients } \\
\text { Beta }\end{array}$} & \multirow[t]{2}{*}{$\mathrm{t}$} & \multirow[t]{2}{*}{ Sig. } & \multicolumn{2}{|c|}{ Collinearity Statistics } \\
\hline & & $\mathrm{B}$ & Std. Error & & & & Tolerance & VIF \\
\hline \multirow[t]{4}{*}{1} & (Constant) & 74.456 & 2.155 & & 34.551 & .000 & & \\
\hline & Google_Classroom & .111 & .039 & .425 & 2.875 & .006 & .634 & 1.577 \\
\hline & $\begin{array}{l}\text { Intensitas } \\
\text { Pemberian Tugas }\end{array}$ & .072 & .031 & .307 & 2.308 & .025 & .782 & 1.279 \\
\hline & Fasilitas_Belajar & -.186 & .083 & -.353 & -2.255 & .028 & .567 & 1.762 \\
\hline
\end{tabular}

a. Dependent Variable: Hasil_Belajar_Akmen

Selanjutnya adalah melakukan uji multikolinearitas dengan hasil uji yang menunjukkan hasil analisis bahwa google classroom memiliki nilai VIF sebesar 1,577 < 10 yang berarti bahwa google classroom tidak berkorelasi sempurna, variabel intensitas pembelajaran tugas memiliki nilai VIF sebesar 1,279 < 10 yang berarti bahwa intensitas pemberian tugas tidak berkorelasi sempurna, dan fasilitas belajar memiliki nilai VIF sebesar 1,762 < 10 yang berarti bahwa variabel fasilitas belajar tidak berkorelasi sempurna. Serta nilai signifikansinya semua variabel independen $>0,10$ yang bermakna data tidak terjadinya multikolinearitas. Sehingga dapat disimpulkan bahwa hasil uji multikolinearitas dari ketiga variabel tersebut menunjukkan tidak adanya gejala multikolinearitas pada model agresi ini. 
1503 Pengaruh Google Classroom, Intensitas Pemberian Tugas, dan Fasilitas Belajar Terhadap Hasil Belajar Akuntansi Manajemen pada Mahasiswa Pendidikan Akuntansi - Venyta Dwi Agmerda, Suci Rohayati

DOI: https://doi.org/10.31004/edukatif.v4i1.2243

\section{Uji Hesteroskedasitas}

\section{Tabel 5}

Uji Hesteroskedasitas

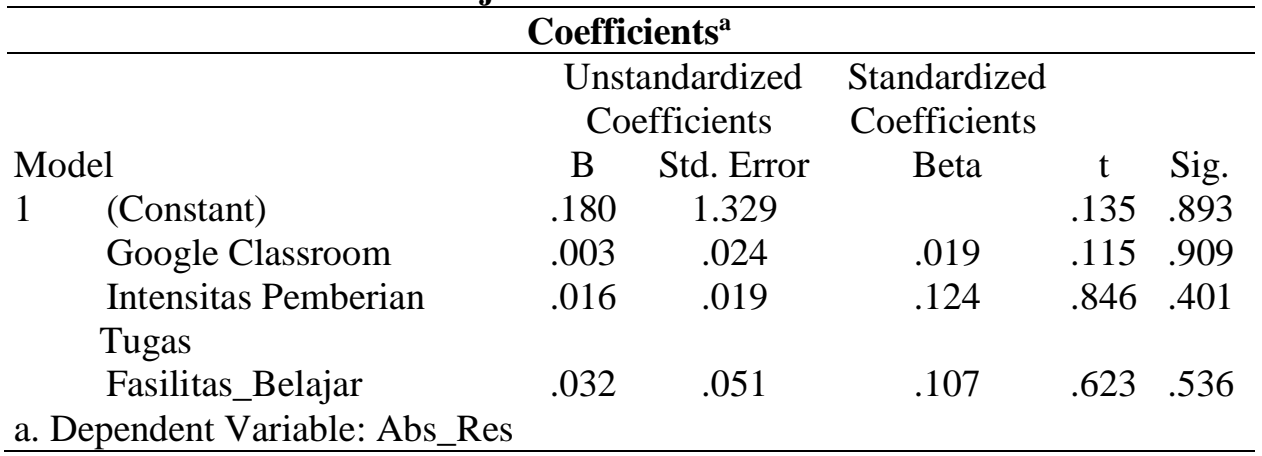

Hasil uji hesteroskedasitas diperoleh hasil pada tabel diatas semua nilai sig. variabel independent > 0,05. Selain itu hasil yang diperoleh dengan menggunakan grafik scatterplot dengan diperoleh hasil data yang menyebar secara acak atau bisa dikatakan pada pola tertentu tidak terbentuk maka hasil analisis menyatakan bahwa tidak terdapat gejala adanya heteroskedasitas dalam model regresi penelitian ini.

Setelah dilakukan uji asumsi klasik, langkah selanjutnya beserta penjabaran pembahasannya yakni:

\section{Hasil Analisis Regresi Linier Berganda}

\section{Tabel 6}

Hasil Analisis Regresi Linier Berganda

\begin{tabular}{|c|c|c|c|c|c|c|}
\hline \multicolumn{7}{|c|}{ Coefficients $^{\mathrm{a}}$} \\
\hline \multirow{8}{*}{$\begin{array}{l}\text { Model } \\
1\end{array}$} & & \multicolumn{5}{|c|}{ Standardize } \\
\hline & & \multirow{2}{*}{\multicolumn{2}{|c|}{$\begin{array}{l}\text { Unstandardized } \\
\text { Coefficients }\end{array}$}} & \multirow{2}{*}{\multicolumn{2}{|c|}{$\begin{array}{c}\mathrm{d} \\
\text { Coefficients }\end{array}$}} & \multirow[b]{3}{*}{ Sig. } \\
\hline & & & & & & \\
\hline & & $\mathrm{B}$ & Std. Error & Beta & $\mathrm{t}$ & \\
\hline & (Constant) & 74.456 & 2.155 & & 34.551 & .000 \\
\hline & Google Classroom & .111 & .039 & .425 & 2.875 & .006 \\
\hline & $\begin{array}{l}\text { Intensitas Pemberian } \\
\text { Tugas }\end{array}$ & .072 & .031 & .307 & 2.308 & .025 \\
\hline & Fasilitas Belajar & -.186 & .083 & -.353 & -2.255 & .028 \\
\hline
\end{tabular}

Mengacu pada tabel.6 guna memproleh hasil regresi dengan:

$\mathrm{Y}=74,456+0,111 \mathrm{X} 1+0,072 \mathrm{X} 2-0,186 \mathrm{X} 3+\mathrm{e}$

Dari hasil persamaan diatas bermakna (1) konstanta 74,456 berarti bila variabel google classroom (X1), intensitas pemberian tugas (X2), dan fasilitas belajar (X3) bernilai 0, maka hasil belajar akuntansi manajemen (Y) bernilai 74,456. (2) Koefisien regresi linier berganda pada variabel google classroom (X1) yakni 0,111; berarti jika X1 naik 1 satuan, sedangkan intensitas pemberian tugas (X2) dan fasilitas belajar (X3) bernilai tetap, maka hasil belajar akuntansi manajemen (Y) akan naik dengan nilai 0,111. (3) Koefisien regresi linier berganda pada intensitas pemberian tugas (X2) yakni 0,072; maknanya jika intensitas pemberian tugas (X2) naik 1 satuan, sedangkan variabel google classroom (X1) dan fasilitas belajar (X3) bernilai tetap, maka hasil belajar akuntansi manajemen (Y) akan naik menjadi 0,072. (4) Koefisien regresi linier berganda pada fasilitas belajar (X3) yakni -0,186; maknanya jika fasilitas belajar (X3) naik 1 satuan, sedangkan google classroom (X1) dan intensitas pemberian tugas (X2) bernilai tetap, maka hasil belajar akuntansi manajemen (Y) akan turun menjadi -0,186 dan di asumsikan bahwa variabel yang lainnya konstan. 
1504 Pengaruh Google Classroom, Intensitas Pemberian Tugas, dan Fasilitas Belajar Terhadap Hasil Belajar Akuntansi Manajemen pada Mahasiswa Pendidikan Akuntansi - Venyta Dwi Agmerda, Suci Rohayati

DOI: https://doi.org/10.31004/edukatif.v4i1.2243

\section{Hasil Uji F (Pengujian Secara Simultan)}

Tabel 7

Hasil Uji F (Pengujian Secara Simultan)

\begin{tabular}{llccccc}
\hline \multicolumn{7}{c}{ ANOVA $^{\mathbf{a}}$} \\
\hline Model & & Sum of Squares & df & Mean Square & F & Sig. \\
1 & Regression & 64.543 & 3 & 21.514 & 5.045 & $.004^{\text {b }}$ \\
& Residual & 243.097 & 57 & 4.265 & & \\
Total & 307.639 & 60 & & & \\
\hline
\end{tabular}

$$
\begin{aligned}
F_{\text {tabel }} & =\mathrm{F}(\mathrm{k}: \mathrm{n}-\mathrm{k}) \\
& =\mathrm{F}(3: 61-3) \\
& =\mathrm{F}(3: 58) \\
& =2,77
\end{aligned}
$$

Berlandaskan pada tabel.7 bahwasanya hasil $F_{\text {hitung }}$ yakni 5,045 $>F_{\text {tabel }}$ yakni 2,77 sedangkan untuk jumlah nilai sig. $0,004<0,05$. Sehingga bisa dikatakan bahwasanya variabel google classroom, intensitas pemberian tugas dan fasilitas belajar dengan Bersamaan atau simultan tidak memberikan pengaruh signifikan terhadap hasil belajar akuntansi manajemen.

\section{Hasil Uji T (Pengujian Secara Parsial)}

Tabel 8

Hasil Uji T (Pengujian secara Parsial)

\begin{tabular}{llccccc}
\hline \multicolumn{7}{c}{ Coefficients $^{\mathbf{a}}$} \\
\hline \multicolumn{5}{c}{ Unstandardized } & \multicolumn{2}{c}{ Standardized } \\
Model & & Coefficients & Coefficients \\
1 & B & Std. Error & Beta & t & Sig. \\
& (Constant) & 74.456 & 2.155 & & 34.551 & .000 \\
& Google_Classroom & .111 & .039 & .425 & 2.875 & .006 \\
& Intensitas_Pemberian_Tugas & .072 & .031 & .307 & 2.308 & .025 \\
& Fasilitas_Belajar & -.186 & .083 & -.353 & -2.255 & .028 \\
\hline
\end{tabular}

Mengacu tabel.8 memperlihatkan hasil uji t pada variabel google classroom, intensitas pemberian tugas dan fasilitas belajar yakni: (1) google classroom dikatakan positif dan signifikan pada hasil belajar akuntansi manajemen dengan hasil $t_{\text {hitung }} 2,875>t_{\text {tabel }} 2,002$ yang mana nilai sig. 0,006 $<0,05$. (2) intensitas pemberian tugas dikatakan berpengaruh secara positif serta signifikan terhadap hasil belajar akuntansi manajemen dengan hasil $t_{\text {hitung }} 2,308>t_{\text {tabel }} 2,002$ yang mana nilai sig. $0,025<0,05$. (3) fasilitas belajar dikatakan berpengaruh secara negatif dan tidak signifikan pada hasil belajar akuntansi manajemen dengan nilai $\mathrm{t}_{\text {hitung }}-2,225<\mathrm{t}_{\text {tabel }}$ 2,002 yang mana nilai sig. $0,028<0,05$.

Pada saat yang sama, Nilai standardized coefficients beta menunjukkan adanya variabel bebas yang mempengaruhi dengan cukup besar ke variabel terikat. Jika diurutkan ada variabel yang mempengaruhi hasil belajar akuntansi manajemen dengan begitu besar yakni variabel google classroom bernilai 0,425 , intensitas pemberian tugas bernilai 0,307 dan variabel fasilitas belajar bernilai -0,353 .

\section{Hasil Pengujian R2 (Koefisien Determinasi)}

\section{Tabel 9}

Hasil Pengujian R2 (Koefisien Determinasi)

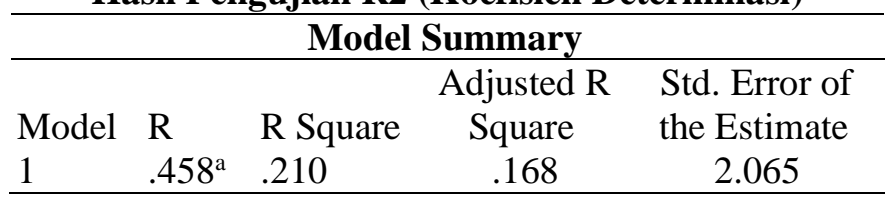


1505 Pengaruh Google Classroom, Intensitas Pemberian Tugas, dan Fasilitas Belajar Terhadap Hasil Belajar Akuntansi Manajemen pada Mahasiswa Pendidikan Akuntansi - Venyta Dwi Agmerda, Suci Rohayati

DOI: https://doi.org/10.31004/edukatif.v4i1.2243

Berlandaskan pada tabel.9 nilai $\mathrm{R}$ square 0,168. Ini maknanya bahwa google classroom, intensitas pemberian tugas dan fasilitas belajar mempengaruhi variabel hasil belajar akuntansi manajemen senilai $21 \%$. Sedangkan nilai sisanya yakni 79\% dipengaruhi variabel diluar penelitian ini.

\section{Pengaruh Google Classroom, Intensitas Pemberian Tugas dan Fasilitas Belajar terhadap Hasil Belajar Akuntansi Manajemen}

Setelah pelaksanaan uji $\mathrm{F}$ diperoleh hasil $F_{\text {hitung }} 5,045>F_{\text {tabel }} 2,77$ dan nilai signifikansinya $0,004<$ 0,05. Demikian bisa ditarik kesimpulan bahwasanya terdapat pengaruh secara simultan antara google classroom, intensitas pemberian tugas dan fasilitas belajar terhadap hasil belajar akuntansi manajemen. Dengan Koefisien determinasi (R2) yang terletak di Adjusted $R$ Square didapatkan nilai 0,168 yang maknanya google classroom, intensitas pemberian tugas dan fasilitas belajar memiliki konstribusi senilai 16,8\% terhadap hasil belajar akuntansi manajemen.

Koefisian determinasi (R2) bermakna ketiga dari variabel independen yakni google classroom, intensitas pemberian tugas dan fasilitas belajar memberikan konstribusi kepada mahasiswa prodi pendidikan akuntansi agar dapat meningkatkan hasil belajar dari matakuliah akuntansi manajemen. Perihal tersebut dikarenakan adanya tingginya pengaruh google classroom dalam pemanfaat e-learning. Pemanfaat e-learning yang baik dapat meninjau tingkat kesuksesan pada mahasiswa dalam mengikuti matakuliah akuntansi manajemen. Intensitas pemberian tugas dapat mempengaruhi hasil belajar akuntansi manajemen karena bertambahnya latihan soal, dan penjelasan materi dari pendidik dapat meningkatkan pengetahuan mahasiswa. Selain itu, adanya fasilitas belajar untuk menunjang kegiatan perkuliahan mahasiswa yang akan mempengaruhi peningkatan hasil belajar tersebut.

Hasil penelitian inii sesuai dengan teori (Seto et al., 2020) yang menjelaskan penerapan pembelajaran online, perolehan hasil belajar yang optimal sangat bergantung kepada kemampuan mahasiswa dalam beradaptasi selama pembelajaran (Seto et al., 2020) Keberhasilan pembelajaran ini terjadi karena adaptasi siswa terhadap metode pembelajaran baru yakni secara tidak langsung. Melalui pembelajaran Google Classroom siswa tetap dapat secara optimal memahami materi yang diperoleh, dan mengeksekusi kegiatan belajar dengan baik, lalu ketersediaan fasilitas belajar yang memumpuni juga akan membantu siswa dalam kelancaran proses belajar dan intensitas pemberian tugas untuk bahan evaluasi siswa dalam mengelola hasil pembelajaran yang telah diterimanya.

Hasil penelitian ini sesuai dengan penelitian yang telah dilakukan oleh (Astuti et al., 2018) yang menyimpulkan apabila adanya hasil yang positif dari fasilitas belajar yang tersedia secara individu dan dari sekolah akan meningkatkan hasil prestasi siswa dalam akademik. Yang berarti media online Google Classroom dan alat belajar sebagai fasilitas online maupun offline memiliki hubungan yang positif dalam hasil belajar, sehingga menambahan intensitas pemberian tugas dapat dicapai dengan baik melalui pemanfaatan media belajar tersebut.

\section{Pengaruh Google Classroom terhadap Hasil Belajar Akuntansi Manajemen}

Pada uji $\mathrm{T}$ diperoleh nilai $t_{\text {hitung }} 2,875>t_{\text {tabel }}$ 2,002 dengan nilai sig. 0,006 $<0,05$. Jadi bisa disimpulkan terdapat pengaruh secara positif dan signifikan antara google classroom terhadap hasil belajar akuntansi manajemen. Google Classroom bisa dinyatakan sebagai media pembelajaran yang berbasis internet guna untuk membantu dalam memfasilitasi terlaksananya proses pembelajaran dan tersampaikannya ilmu pengetahuan. Dengan demikian, semakin tinggi pengaruh yang disumbangkan dari google classroom maka semakin tinggi pula tingkat pengetahuan mahasiswa dalam melaksanakan tugasnya, begitupun sebaliknya.

Hasil sepemikiran dengan (JUFRI, 2020) menyebutkan secara parsial google classroom berdampak secara positif serta memiliki signifikansi yang lemah guna hasil belajar pada mahasiswa. Persamaan penelitian yang dilakukan oleh (Kantun, 2017) yang berpendepat bahwa pembelajaran online berbasis e-learning secara 
1506 Pengaruh Google Classroom, Intensitas Pemberian Tugas, dan Fasilitas Belajar Terhadap Hasil Belajar Akuntansi Manajemen pada Mahasiswa Pendidikan Akuntansi - Venyta Dwi Agmerda, Suci Rohayati

DOI: https://doi.org/10.31004/edukatif.v4i1.2243

signifikan membantu meningkatkan hasil belajar dan motivasi siswa. Hal ini menjelaskan bahwa perlembangan teknologi dapat membantu dalam aspek pendidikan dalam meningkatkan hasil elajar. Terutama di perguruan tinggi, dalam membantu proses belajar mengajar. Dalam pelaksaan pemeblajaran online terdapat dampak yang baik dan buruk, dampak baik nya adalah pembelajaran yang dapat dilakukan dimanapun dan kapanpun, mempermudah dalam pengaksesan, dan materi belajar dapat disimpan dan dapat dibuka untuk dipahami kembali. Kemudahan pembelajaran online akan menghasilkan proses belajar yang efektif dan efisien. Dan dampak buruknya adalah terjadinya komunikasi secara tidak langsung, fasilitas belajar dan hubungan interet yang berbeda setiap daerah, komunikasi satu arah sehingga berdampak untuk salah persepsi atau memahaman siswa, kurangnya perhatian dalam kelompok belajar, sehingga beberapa siswa erasa kurang diperhatikan perkembangnnya.

\section{Pengaruh Intensitas Pemberian Tugas terhadap Hasil Belajar Akuntansi Manajemen}

Berlandaskan hasil pengujian $\mathrm{t}$ memperoleh $t_{\text {hitung }} 2,308>t_{\text {tabel }} 2,002$ dengan nilai signifikansi $0,025<0,05$. Oleh karena itu bisa disebutkan bahwa intensitas pemberian tugas berpengaruh secara positif serta signifikan untuk hasil belajar akuntansi manajemen. Pemberian tugas pada masa pembelajaran online dapat meningkatkan rasa tanggung jawab pada mahasiswa dalam ketepatan waktu pengumpulan dikarenakan apabila terlewat dapat mempengaruhi hasil belajar (Susilo \& Pancarani, 2020). Hal ini dapat diartikan tugas yang diberikan Dosen kepada para mahasiswanya sebagai bentuk umpan balik untuk penilaian (assessment) atas proses pembelajaran pada saat berlangsung.

Hasil penelitian tersebut sependapat dengan (Parni \& Listiadi, 2020) yang menguraikan bila intensitas pemberian tugas berdampak secara positif untuk hasil belajar akuntansi pada mahasiswa. Penambahan tugas ini dilakukan dalam rangka agar para siswa dapat memaksimalkan waktu luang nya, hal ini dilakukan juga untuk meningkatkan kegiatan pembelajaran secara mandiri dengan aktif, sehingga memicu terhadinya diskusi diluar pembelajaran. Ketika siswa diberikan penugasan, kualitas atau ukuran pencapaiannya bukan pada hasilnya namun pada sikap ketekunan dalam menyelesaikan tugas serta tanggung jawab terhadap proses belajar mandiri. Intensitas pemberian tugas ini akan membuat siswa memperdalam pembahsan materi yang telah diulang ketika dikelas online, sehingga mereka akan cenderung membaca kembali pada saat penyelesaian tugas rumah, sehingga materi itu akan melekat dan akan menghasilkan pemahaman materi yang lebih optimal, dengan demikian dapat membantu dalam meningkatkan hasil belajar siswa.

\section{Pengaruh Fasilitas Belajar terhadap Hasil Belajar Akuntansi Manajemen}

Berdasarkan uji t memperoleh hasil $t_{\text {hitung }}-2,255<t_{\text {tabel }} 2,002$ dengan nilai signifikansinya $0,028<$ 0,05. Sehingga disimpulkan fasilitas belajar mempengaruhi secara negatif serta tidak signifikan pada hasil belajar akuntansi manajemen. Fasilitas belajar dapat ditentukan dengan sumber belajar, alat belajar dan pendukung belajar. Masalah dalam pembelajaran online antara lain pengawasan yang lemah, biaya kuota yang mahal dan jaringan yang buruk di daerah pelosok (Sadikin \& Hamidah, 2020).

Hasil ini sesuai penelitian (Kristiana Nia, 2020) yang dikemukakan bila fasilitas belajar berdampak negatif serta tidak signifikan guna hasil belajar pada mahasiswa. Persaamn penelitian oleh (Fijar et al., 2018) menyatakan bahwa hasil belajar dipengaruhi oleh fasilitias belajar di rumah sebesar 30,5\% dengan signifikansi tinggi. Dan kesimpulan penelitian (Sadikin \& Hamidah, 2020) membuktikan bahwa fasilitas belajar berkontribusi pada hasil belajar sebesar $28,6 \%$ dan signifikansinya $<0,05$. Menurut The Liang Gie (dalam Muzdalifatuz, 2017) fasilitas belajar bisa ditentukan dengan sumber belajar, alat belajar dan pendukung belajar. Apabila lingungan keluarga mendukung dengan memberikan fasilitas yang memadai, maka akan membantu siswa dalam pelaksaan proses belajarnya. Dalam belajar, siswa membutuhkan lngkungan yang nyaman, dan bahan ajar dan peralatan yang sesuai untk membantu mempermudah pelaksaan pembelajaran. Fasilitas belajar yang lengkap dan baik nantinya akan dipergunakan sebagai alat mempermudah siswa 
1507 Pengaruh Google Classroom, Intensitas Pemberian Tugas, dan Fasilitas Belajar Terhadap Hasil Belajar Akuntansi Manajemen pada Mahasiswa Pendidikan Akuntansi - Venyta Dwi Agmerda, Suci Rohayati

DOI: https://doi.org/10.31004/edukatif.v4i1.2243

mengikuti kelas online serta media penugasan, karena pembelajaran online cenderung lebih banyak memberikan penugasan yang membutuhkan fasilitas dan teknologi untuk membantu dan memudahkan siswa dalam belajar. Fasilitas akan membantu akan pemahaman materi oleh siswa dan juga mempermudah dalam mengikuti kelas online hingga penugasan yang telah berhsil dilaluinya. yang dengan demikian dapat membantu meingkatkan hasil belajarnya.

\section{KESIMPULAN}

Berlandaskan pada penjabaran hasil maka kesimpulannya yakni secara simultan terdapat pengaruh positif serta signifikan google classroom, intensitas pemberian tugas dan fasilitas belajar terhadap hasil belajar akuntansi manajemen. Perihal tersebut bisa dilihat melaluihasil uji $\mathrm{T}$ yang menjabarkan bahwasanya google classroom berpengaruh secara positif serta signifikan terhadap hasil belajar akuntansi manajemen. Intensitas pemberian tugas memberikan pengaruh positif serta signifikan untuk hasil belajar akuntansi manajemen. Fasilitas belajar memberikan pengaruh secara negatif serta tidak signifikan terhadap hasil belajar akuntansi manajemen.Berlandaskan pada hasil analisa dan pembahasan maka kesimpulannya yakni: 1).Penelitian ini mampu memberikan kontribusi wawasan kepada pembaca perihal pengaruh google classroom, intensitas pemberian tugas dan fasilitas belajar terhadap hasil belajar akuntansi manajemen. 2) Hasil penenlitian ini dapat menjadi acuan guna peneliti selanjutnya dengan catatan memiliki topik permasalahan yang selinier.

\section{UCAPAN TERIMA KASIH}

1. Terima kasih kepada Dosen Pembimbing saya yang membantu dan mendukung penelitian ini.

2. Terima kasih kepada Prodi Pendidikan Akuntansi Universitas Negeri Surabaya yang telah membantu dan mendukung penelitian ini.

\section{DAFTAR PUSTAKA}

Afrianti, W. E. (2018). Penerapan Google Classroom dalam Pembelajaran Akuntansi (Studi Pada Program Studi Akuntansi Universitas Islam Indonesia) Universitas Islam Indonesia (Online). https://scholar.google.co.id/

Alessandro, B. (2018). Digital Skills and Competence, and Digital and Online Learning. Turin: European Training Foundation.

Andiarna, F., Widayanti, L. P., Hidayati, I., \& Agustina, E. (2020). Analisis Penggunaan Media Sosial Terhadap Kejadian Insomnia Pada Mahasiswa. Profesi (Profesional Islam) : Media Publikasi Penelitian, 17(2), 37-42.

Anugrahana, A. (2020). Hambatan, Solusi dan Harapan: Pembelajaran Daring Selama Masa Pandemi Covid19 Oleh Guru Sekolah Dasar. Jurnal Pendidikan dan Kebudayaan, 10(3), 282-289.

Aristianti, L., \& Listiadi, A. (2016). Pengaruh Pemahaman Perpajakan, Intensitas Pemberian Tugas dan Gaya Belajar Terhadap Hasil Belajar Akuntansi Perpajakan dengan Motivasi Belajar sebagai Variabel Moderating Pada Mahasiswa Pendidikan Akuntansi Fakultas Ekonomi Universitas Negeri Surabaya. Jurnal Pendidikan Akuntansi (JPAK), 4(3).

Atsrivah \& Listiadi A. (2021). Peran Motivasi Belajar dalam Memoderasi Pengaruh Efikasi Diri, Fasilitas Belajar dan Intensitas Pemberian Tugas terhadap Hasil Belajar Akuntansi Perpajakan. Jurnal Universitas Negeri Jember, 15(2), 221-230.

Basar, A.M. (2021). Problematika Pembelajaran Jarak Jauh Pada Masa Pndemi Covid-19 (Studi Kasus di SMPIT Nurul Fajri - Cikarang Barat - Bekasi). Jurnal Ilmiah Pendidikan, 2(1). https://doi.org/10.51276/edu.v2i1.112

Buku Pedoman Fakultas Ekonomi Universitas Negeri Surabaya. 
1508 Pengaruh Google Classroom, Intensitas Pemberian Tugas, dan Fasilitas Belajar Terhadap Hasil Belajar Akuntansi Manajemen pada Mahasiswa Pendidikan Akuntansi - Venyta Dwi Agmerda, Suci Rohayati

DOI: https://doi.org/10.31004/edukatif.v4i1.2243

Ervina, L. (2016). Pengaruh Pemahaman Perpajakan, Intensitas Pemberian Tugas dan Motivasi Belajar Terhadap Hasil Belajar Akuntansi Perpajakan Pada Mahasiswa Pendidikan Akuntansi Universitas Negeri Surabaya. Jurnal Pendidikan Akuntansi (JPAK), 4(2). https://ejournal.unesa.ac.id/index.php/jpak/article/view/32738

Fijar, N. Y., Muchtar, B., \& Idris, I. (2018). The Effect of Parental Attention, Home Study Facilities and Learning Motivation on Students Learning Outcome (Research: Social Sciense Subject in District Sungayang High School Tanah Datar Regency). Jurnal Aplikasi IPTEK Indonesia, 2(2), 98-103. https://doi.org/10.24036/4.22120

Hakim, A. B. 2016. Efektifitas Penggunaan E-Learning Moodle, Google Classroom dan Edmodo. STIMIK ESQ

Hammi, Zedha. (2017). Implementasi Google Classroom Pada Kelas XI IPA MAN 2 Kudus. Universitas Negeri Semarang

id.cips-indonesia.org. 2020. Ringkasan Kebijakan Mengkaji Hambatan Pembelajaran Jarak Jauh di Indonesia di Masa Covid-19. (https://id.cips-indonesia.org/post/ringkasan-kebijakan-mengkaji-hambatanpembelajaran-jarak-jauh-di-indonesia-di-masa-covid-19-3, diakses pada 8 Oktober 2021).

Imaduddin, Muhammad. 2018. Membuat Kelas Online Berbasis Android dengan Google Classroom: Terobosan Pembelajaran Era Revolusi Industri 4.0. Yogyakarta: Garudhawaca.

Jufri, A. (2020). Pengaruh Penggunaan Google Classroom Terhadap Hasil Belajar Mahasiswa Kelas A Angkatan 2017 (Program Studi Pendidikan Sosiologi Universitas Muhammadiyah Makassar). Skripsi Dipublikasikan. Universitas Muhammadiyah Makassar: Makassar

Kristiana, Nia. (2021). Pengaruh Pembelajaran Online Melalui Google Classroom dan Fasilitas Belajar Terhadap Hasil Belajar Matematika Pada Siswa Kelas VIII SMP Negeri 4 Salatiga Tahun Pelajaran 2020/2021. Perpustakan IAIN Salatiga. http://e-repository.perpus.iainsalatiga.ac.id/id/eprint/10184

Parni, \& Listiadi, A. (2020). Peran Motivasi Belajar Dalam Memoderasi Pemahaman Perpajakan, Intensitas Pemberian Tugas, Dan Kebiasaan Belajar Terhadap Hasil Belajar Akuntansi Perpajakan. Jurrnal Pendidikan Ekonomi, 13(2), 165-175.

Patliana, \& Purwati, T. (2020). Pengaruh Pemberian Tugas Rumah Secara Daring di Masa Pandemi Wabah Covid-19 terhadap Hasil Belajar IPS Siswa Kelas VII di SMP IT Darul Ikhsan NW Balik Batang Tahun Ajaran 2019 / 2020. Prosiding Seminar Nasional IKIP Budi Utomo, 450-455.

Rosidah, E., Arrahmah, G., \& Marliana, R. (2018). Akuntansi Manajemen Edisi 1. Bandung: Mujahid Press.

Sadikin, A., \& Hamidah, A. (2020). Pembelajaran Daring di Tengah Wabah Covid-19:(Online Learning in the Middle of the Covid-19 Pandemic). Biodik, 6(2), 214-224.

Seto, S. B., Suryani, L., \& Bantas, M. G. D. (2020). Analisis Efikasi Diri Dan Hasil Belajar Berbasis ELearning Pada Mahasiswa Program Studi Pendidikan Matematika. Prima Magistra: Jurnal Ilmiah Kependidikan, 1(2), 147-152. https://doi.org/10.37478/jpm.v1i2.472

Susilo, G., \& Pancarani, N. (2020). Kemandirian Belajar Mahasiswa Melalui Blended Learning Mata Kuliah Kalkulus Lanjut Era Pandemi Covid-19. Journal.Lppmunindra, 2682(1), 37-48. http://journal.lppmunindra.ac.id/index.php/jkpm/

Tsabitah, D., \& Wahyudin, A. (2016). Peran Kesiapan Belajar Dalam Memediasi Pengaruh Kesiapan Belajar Dan Fasilitas Belajar Terhadap Hasil Belajar Akuntansi. Economic Education Analysis Journal, 5(1), 72-84.

Wicaksono, V. D., \& Rachmadyanti, P. (2017). Pembelajaran Blended Learning Melalui Google Classroom di Sekolah Dasar. Seminar Nasional Pendidikan PGSD UMS \& HDPGSDI Wilayah Jawa (pp. 513521). Surakarta: Universitas Muhammadiyah Surakarta. 
1509 Pengaruh Google Classroom, Intensitas Pemberian Tugas, dan Fasilitas Belajar Terhadap Hasil Belajar Akuntansi Manajemen pada Mahasiswa Pendidikan Akuntansi - Venyta Dwi Agmerda, Suci Rohayati

DOI: https://doi.org/10.31004/edukatif.v4i1.2243

Sugiyono. (2017). Metode Penelitian Kuantitatif Kualitatif dan $R \& D$. Bandung : Alfabeta 